\title{
STRATEGI PENGAMBILAN KEPUTUSAN DALAM MENGOPTIMALKAN ASUHAN KEPERAWATAN
}

\author{
Try Ayu Amanda Pasaribu \\ tryayuamanda08@gmail.com
}

\section{Latar Belakang}

Perawat merupakan tenaga professional yang bertanggung jawab dalam memberikan proses keperawatan kepada klien. Asuhan keperawatan bermutu dapat meningkatkan kemampuan berfikir kritis perawat dalam melakukan pelayanannya. Pelayanan keperawatan didasarkan dengan pendekatan pengambilan keputusan yang ditingkatkan dengan berfikir kritis. Pengambilan keputusan dalam keperawatan merupakan adalah hal yang sangat penting karena akan memengaruhi asuhan keperawatan yang karena diberikan.Pengambilan Keputusan adalah kegiatan untuk mengumpulkan informasi dan memilih suatu tindakan dari beberapa alternatif pilihan yang tersedia, terutama yang dilakukan oleh tenaga paramedis, saat gawat darurat.

Pengambilan keputusan klinik keperawatan merupakan sebuah proses penilaian yang dilakukan oleh perawat setiap hari terhadap proses pelayanan yang diberikan kepada pasien. Adapun pengambilan keputusan merupakan suatu pemilihan dari berbagai alternatif dengan menetapkan suatu pilihan yang dianggap paling penting untuk memenuhi kepentingan tertentu. Demikian halnya dalam keperawatan, pengambilan keputusan tindakan yang diberikan kepada seorang pasien akan mempengaruhi proses penyembuhan atau pelayanan yang diberikan. Dalam pengambilan keputusan perawat harus mempertimbangkan segala aspek, baik dari pasien itu sendiri, keluarga pasien, tenaga kesehatan lain, dan psiko, sosial, dan cultural yang diterapkan, Perawat juga harus ikut membantu klien ataupun keluarga klien dalam mengambil keputusan yang berhubungan dengan kesehatan klien. Untuk mengambil keputusan tersebut perlu dilakukan analisa berupa diagnosa keperawatan. Diagnosa keperawatan adalah keputusan klinis mengenai seseorang, keluarga, atau masyarakat sebagai akibat dari masalah kesehatan atau proses kehidupan yang aktual atau proses kehidupan.

Suatu strategi adalah rencana keseluruhan yang penuh seni atau baik terhadap penetapan metode dan teknik dalam mengejar suatu tujuan. Para ahli telah menetapkan strategi pengikut dalam pengambilan keputusan. Setiap strategi terutama sekali cocok dengan jenis khusus dari masalah dan keadaan yang khusus :

1. Strategi pengoptimalan

2. Strategi pemuasan

3. Strategi kesempatan

4. Strategi yang tidak perlu melakukan sesuatu 
5. Strategi penyelesaian terhadap faktor pembatas yang penting

6. Strategi maksimum

7. Strategi minimum

8. Strategi pencegahan

\section{METODE}

Metode yang digunakan pada kajian ini adalah dengan menganalisis dari berbagai sumber bacaan. Metode yang digunakan pengkajian ini dengan mengumpulkan informasi dari berbagai referensi termasuk didalamnya hasil-hasil penelitian.

Referensi yang saya ambil dari jurnal online, e-book yang mengarah pada topik Strategi Pengambilan Keputusan Dalam Mengoptimalkan Asuhan Keperawatan dan pengerjaannya dengan cara membandingkan artikel satu dengan artikel yang lain.

\section{HASIL}

Hasil dari kajian ini adalah pengambilan keputusan yang baik dari perawat akan mendukung kualitas perawatan yang diberikan kepada pasien tetapi jika tidak didukung dengan pengetahuan dan keterampilan yang baik dari perawat dalam melakukan pengambilan keputusan klinik keperawatan maka akan menurunkan mutu dan kualitas dari proses keperawatan yang diberikan kepada pasien (Jurnal Determinan Pengambilan Keputusan Klinik Keperawatan di RSUD Arifin Achmad Provinsi Riau. Susi Erianti(2019)). Pengambilan keputusan merupakan suatu pendekatan sistematis untuk menyelesaikan suatu masalah. Pengambilan keputusan yang tepat menggunakan suatu pendekatan yang sistematis terhadap hakekat suatu masalah dengan pengumpulan fakta-fakta dan data. Pengambilan keputusan dalam penyelesaian masalah membutuhkan kemampuan yang mendasar bagi praktisi kesehatan, khususnya dalam asuhan keperawatan. Pengambilan keputusan tidak hanya berpengaruh pada proses pengelolaan asuhan keperawatan, tetapi penting untuk meningkatan kemampuan merencanakan perubahan. Perawat pada semua tingkatan posisi klinis harus memiliki kemampuan menyelesaikan masalah dan mengambil keputusan yang efektif, baik sebagai pelaksana/staf maupun sebagai pemimpin (Jurnal Pengaruh Empowerment Terhadap Pengambilan Keputusan Perawat. Imran Pashar(2020)).

Perawat harus mempertimbangkan banyak faktor yang berpotensi mempengaruhi proses pengambilan keputusan dalam memenuhi kebutuhan pasien. Perawat harus mempunyai kemampuan yang baik untuk pasien maupun dirinya didalam menghadapi masalah yang menyangkut etika. Seseorang harus berpikir secara rasional, bukan emosional dalam membuat 
keputusan etis. Keputusan tersebut membutuhkan keterampilan berpikir secara sadar yang diperlukan untuk menyelamatkan keputusan pasien dan memberikan asuhan. Kemampuan membuat keputusan masalah etis menjadi salah satu persyaratan bagi perawat untuk menjalankan praktik keperawatan professional.

Pengambilan keputusan dengan konsep berfikir kritis dalam keperawatan merupakan hal yang kompleks, karena menyangkut permasalahan manusia. Berfikir kritis merupakan kemampuan yang harus di asa oleh perawat maupun mahasiswa keperawatan karena dengan adanya bekal kemampuan berpikir kritis seorang perawat akan mempunyai keberanian untuk mengambil keputusan. Untuk mengambil suatu keputusan pun perawat tidak boleh asal-asalan harus memperhatikan banyak hal yang nantinya akan menjadi keputusan yang akurat dan jelas.

Ada dua bentuk yang mempengaruhi gaya pengambil keputusan yaitu: (1) Unifocus, yaitu pengambil keputusan yang cenderung untuk menggunakan informasi untuk menghasilkan satu solusi dalam memecahkan masalah, (2) Multifocus, yaitu pengambil keputusan yang cenderung menggunakan informasi untuk menghasilkan beberapa alternative solusi dalam memecahkan masalah.

Para perawat dan tenaga paramedik mengambil keputusan menggunakan metode pengambilan keputusan yang berdasarkan pada empat hal yaitu; (1) berdasarkan pengalaman, (2) berdasarkan standar/prosedur tetap yang suda ada, (3) berdasarkan pendidikan/teori yang dimiliki, dan (4) berdasarkan pertimbangan orang yang lebih ahli. Para perawat dan tenaga paramedik mengambil keputusan dengan gaya pengambilan keputusan tipe decisive dan tipe fleksible sesuai dengan bidang pelayanan jasa khususnya pelayanan di unit kegawat daruratan dan model bekerja secara tim.

Perawat memiliki tanggung jawab dan kewenangan untuk mengambil langkah-langkah keperawatan yang diperlukan sesuai dengan standar keperawatan. Pelayanan keperawatan di Indonesia di masa depan diperkirakan juga akan menuju pelayanan atau asuhan keperawatan profesional yang bersifat holistik dan humanistik, berlandaskan ilmu dan kiat Keperawatan dengan etika keperawatan sebagai tuntunan. Kemampuan para perawat dan tenaga paramedis dalam kondisi kondisi kritis ketika menangani pasien tentu tidak lepas dari latar belakang pendidikan yang pernah ditempuh serta pengalaman yang pernah dijalani. Termasuk disini 
adalah kemampuan perawat dan tenaga paramedis dalam mengambil keputusan saat gawat darurat.

Pengambilan keputusan dalam memilih pelayanan akan berdampak juga pada kepuasan dan kenyamanan pasien sebagai penerima pelayanan kesehatan. Demikian halnya dalam keperawatan, pengambilan keputusan tindakan yang diberikan kepada seorang pasien akan mempengaruhi proses penyembuhan atau pelayanan yang diberikan.

\section{PEMBAHASAN}

\section{Pengertian Pengambilan Keputusan}

a) Pengambilan keputusan merupakan proses kognitif yang kompleks dan sering didefinisikan sebagai suatu upaya memutuskan serangkaian tindakan tertentu.

b) Pengambilan keputusan adalah suatu proses dimana pilihan solusi yang tepat ditimbang dan yang paling tepat akan dipilih.

\section{Jenis Keputusan}

a) Keputusan rutin, menggunakan aturan yang telah ditetapkan, kebijakan ,dan prosedur.

b) Keputusan adaptif diperlukan ketika kedua masalah dan solusi alternatif yang agak tidak biasa dan hanya dipahami secara parsial.

\section{Langkah-langkah dalam pengambilan keputusan}

- Tahap 1 menerima tantangan. Pengambilan keputusan dimulai manakala seseorang dihadapkan kepada suatu tantangan terhadap jalur tindakannya yang berlaku.

- Tahap 2 mencari alternatif. Bila suatu jalur tindakan yang sedang berlaku mendapat tantangan, pengambilan keputusan yang efektif mulai mencari alternatif. Individu mempertimbangkan secara matang-matang tujuan-tujuannya serta nilai-nilai yang relevan dengan suatu keputusan. 
- Tahap 3 penilaian alternatif. Pada tapi ini kelebihan-kelebihan serta kekurangankekurangan dari masing-masing alternatif dipertimbangkan dengan cermat tahap ini sering melibatkan upaya yang besar untuk mencari informasi yang dapat dipercaya yang relevan dengan keputusan yang efektif, mencari fakta-fakta serta ramalan dari berbagai ragam sumber berkenaan dengan akibat-akibat dari alternatif alternatif yang sedang dipertimbangkan.

- Tahap 4 menjadi terikat. Pada apa ini pilihan terakhir sudah dibuat dan pengambilan keputusan menjadi terikat kepada suatu jalur tindakan baru. Pengambilan keputusan efektif menelaah kembali segala informasi yang telah terkumpul sebelum mengambil suatu keputusan terakhir. Individu juga memikirkan bagaimana melaksanakan keputusan dan membuat rencana cadangan seandainya ada sesuatu rezeki menjadi kenyataan.

- Tahap 5 berpegang pada keputusan. Setiap pengambil keputusan berharap segalanya akan berjalan lancar sesudah suatu keputusan diambil, tetapi hambatan sering terjadi memilih alternatif terbaik belum mencukupi. Jika keputusan tidak dilaksanakan secara memadai, hasil yang menggembirakan tidak akan tercapai.

Menurut Driver dan Brousseau, terdapat dua faktor kunci yang mempengaruhi gaya pengambilan keputusan yaitu: (1) penggunaan informasi yaitu jumlah informasi yang digunakan dalam proses pengambilan keputusan. (2) fokus yaitu jumlah alternatif yang diidentifikasi dan dipilih untuk mengatasi masalah.

Dari beberapa kutipan dapat dianalisis bahwa proses kognitif yang tersedia selama proses pengambilan keputusan adalah:

- Memusatkan pikiran dan perhatian agar pasien bisa tertolong dan selamat

- Berpikir tentang cara-cara menolong pasien untuk melakukan tindakan

- Memikirkan resiko tindakan yang dilakukan setelah ambil keputusan

- Berpikir menghubungi orang lain (dokter) untuk meminta bantuan

- Tidak memikirkan sesuatu, karena sudah menjadi rutinitas

Beberapa aspek afektif yang terlibat saat mengambil keputusan, antara lain: 
- Perasaan bingung dan ragu-ragu

- Perasaan takut

- Perasaan mantap dan tenang

- Perasaan tegang

- Perasaan kecewa, marah dan kasihan

- Perasaan menerima

\section{Kondisi Pengambilan Keputusan}

1. Pengambilan keputusan berdasarkan kepastian

2. Pengambilan keputusan dalam ketidakpastian dan risiko

Ada tiga cara di mana pembuat keputusan model rasional dalam pengambilan keputusan:

1. Pencarian pengambil keputusan untuk tujuan yang mungkin atau solusi alternatif terbatas karena waktu, tenaga dan uang.

2. Manajer sering kekurangan informasi yang memadai tentang masalah dan tidak dapat mengontrol kondisi di mana mereka beroperasi.

3. Manajer sering menggunakan strategi satisficing.

- Penyelesaian masalah untuk pengambilan keputusan

Perawat yang telah menerapkan perilaku caring ini akan membuat pasien merasa puas dengan asuhan yang diberikan. Ini sesuai dengan pendapat sabarguna dalam Waluyo, yang menjelaskan bahwa pelanggan puas jika layanannya benar, kompeten, ramah, dan menanggapi semua keluhan dengan bijak. Perawat perlu membahas masalah yang menyangkut pasien, memberikan solusi untuk keluhan dan perasaan yang diungkapkan oleh pasien dan menyelesaikan masalah dengan segera. Sikap kepedulian perawat dengan memberikan kontribusi kepada pasien dalam bentuk pertimbangan untuk mengambil keputusan memberikan energi positif diberikan kepada pasien. 
Keputusan klinis yang dibuat perawat harus didukung dengan data yang akurat serta lengkap dan sistem yang baik. Namun dalam pelaksanaan perawatan pasien, pembuatan keputusan klinis oleh perawat tidak didukung dengan sistem pendukung keputusan klinis di rumah sakit. Tujuannya untuk mengetahui sistem pendukung keputusan klinis yang dapat mendukung pembuatan keputusan klinis oleh perawat bagi pelayanan pasien di rumah sakit.

Pengambilan keputusan klinis oleh perawat adalah proses kompleks yang berpotensi mempengaruhi kualitas layanan yang diberikan dan hasil pasien. Sistem pendukung keputusan klinis adalah sistem teknologi informasi kesehatan yang dirancang untuk memberikan dokter dan profesional keputusan klinis, yaitu bantuan dengan tugas-tugas pengambilan keputusan klinis. Secara umum CDSS sudah tersebar secara luas dalam perspektif pemanfaatan, sumber pengetahuan dan sumber data, berbagai jenis dukungan keputusan yang ditawarkan, penyampaian informasi dan pengetahuan ,dan dampak dalam pekerjaan. Sistim pendukung keputusan klinis (CDSS) telah berkembang secara dramatis selama 25 tahun terakhir dan kemungkinan akan berkembang secara dramatis atau lebih.

Perawat dalam mengidentifikasi dan merespon pasien yang memburuk terkadang membuat keputusan secara otonom, salah menafsirkan bukti, tanggapan yang terkondisi dan tidak melihat isyarat. Keputusan klinis yang dibuat perawat harus didukung dengan data yang akurat serta lengkap dan sistem yang baik agar dapat menjawab kebutuhan pasien secara tepat. Sistem pendukung keputusan klinis yang direncanakan dengan baik dan dimasukkan ke dalam layanan kesehatan akan menciptakan layanan yang berkualitas dan meningkatkan efektivitas serta mengurangi biaya perawatan. Pada kenyataannya dalam pelaksanaan perawatan pasien, pembuatan keputusan klinis oleh perawat tidak didukung dengan sistem pendukung keputusan klinis di rumah sakit. Oleh karena itu maka tujuan penulis menyusun literatur review ini adalah untuk mengetahui sistem pendukung keputusan klinis yang dapat mendukung pembuatan keputusan klinis oleh perawat bagi pelayanan pasien di rumah sakit.

Pengambilan keputusan (decision making) merupakan hal yang sangat penting untuk diperhatikan oleh perawat berkaitan dengan kualitas pemberian asuhan keperawatan.

Keputusan harus dapat menjawab pertanyaan tentang apa yang dibicarakan dalam hubungannya dengan perencanaan. Kemudian keputusan dapat pula berupa tindakan terhadaap 
pelaksanaan yang sangat menyimpang dari rencana semula. Untuk mengembangkan kemampuan guna membuat keputusan yang mantap, handal, dan tepat waktumya, dibutuhkan beberapa bekal untuk melakukan hal itu. Pertama; dibutuhkan kemampuan nalar atau pertimbangan yang masak agar setelahmeneliti semua faktor yang berhubungan dengan suatu masalah serta segenap alternatif pemecahannya, mampu menetapkan suatu pemecahan terbaik yang dapat dilaksanakan dengan lancar dan juga dituntut untuk berwawasan jauh ke depan agar dapat mengantisipasi dan merencanakan aksi dan reaksi yang akan muncul akibat keputusan tersebut. Kedua, harus mempunyai kepribadian kuat yang diperlukan untuk membuat keputusan terbaik pada waktu yang tepat, dan mengumumkannya juga pada waktu dan tempat yang tepat sehingga akan diperoleh hasil sesuai yang diharapkan.

\section{Penutup}

Instalasi Gawat Darurat (IGD) merupakan unit pelayanan yang didirikan oleh rumah sakit untuk memberikan pelayanan gawat darurat.

Pengambilan keputusan (Decision making). Pengambilan keputusan adalah suatu hasil atau keluaran dari proses mental atau kognitif yang membawa pada pemilihan di antara beberapa alternatif yang tersedia yang dilakukan oleh seorang pembuat implementasi dari pilihan keputusan yang diambil. Manajemen keperawatan akan melibatkan pengambilan keputusan berbagai situasi maupun permasalahan yang terjadi dalam pengelolaan kegiatan keperawatan memerlukan pengambilan keputusan di berbagai tingkat manajerial. Proses pengambilan keputusan yaitu Pengumpulan data: Identifikasi masalah, perencanaan terdiri dari penentuan tujuan, identifikasi solusi, implementasi, evaluasi dan revisi proses.

Ada tiga bentuk metode dalam mengambil keputusan yaitu, (1) membuat keputusan berdasarkan pengalaman masalalu yang digabungkan dengan perasaan individual/pribadi (2) membuat keputusan berdasarkan kajian/penelaahan/penelitian dn pemecahan masalah (3) mengambil keputusan dengan menggunakan teori gabungan antara perasaan(sense) dan kajian/penelitian/penelaahan ilmiah.

\section{REFERENSI}


1. Aeni Wiwin Nur,Winani,Hendri Sutioso.2019. Perilaku Caring Perawat dalam Memberikan Asuhan Keperawatan di Salah Satu RS di Kabupaten Indramaysu. Jurnal Keperawatan Profesional(JKP). Vol:7(2).

2. Cristine W. Nibbelink, B.B.B.2017. Decision making in nursing practice : An integrative literature review. Physiology \& Behavior, 176 (3). 139-148.

3. Dady Daniel, Kadek Ayu Erika,Rini Rachmawaty.2020. Sistim Pendukung Dalam Pembuatan Keputusan Klinis Perawat Di Ruang Rawat Inap : Literature Review. Jurnal Ilmu Kesehatan. Vol: 8(2). 173-181.

4. Dolan,C.2017. Moral,Ethical,and Legal Decision-making in Controversial NP Pratice Situations. Journal for Nurse Practitioners, 13(2). e57-e65.

5. Erianti,Susi, Rizanda Machmud Harmawati.2019. Determinan Pengambilan Keputusan Klinik Keperawatan di RSUD Arifin Achmad Provinsi Riau. Jurnal Kesehatan Komunitas. Vol:5(3). 227-234.

6. Haryono,R.2012. Etika Keperawatan dengan Pendekatan Praktis(Edisi 1). Jakarta : EGC.

7. Khairina Ilfa,Hema Malini,Emil Huriani.2018. Faktor-Faktor Yang Berhubungan Dengan Pengambilan Keputusan Perawat Dalam Ketepatan Triase di Kota Padang. Indonesian Journal for Health Sciences. Vol:2(1). 1-6.

8. Mugianti.2016. Modul bahan ajar cetak keperawatan : Manajemen dan kepemimpinan dalam praktek keperawatan. Kebayoran Baru Jakarta Selatan.

9. Mukhtadi, Mohammad Rizki.2018. Strategi Pengambilan Keputusan Dalam Pemecahan Masalah (Studi Kasus Pada Bank XYZ Cabang Tajur Halang Cianjur Jawa Barat). Journal of Economics and Business Aseanomics (JEBA). Vol:3(1). 81-99.

10. Pashar,Imran, Luky Dwiantoro.2020. Pengaruh Empowerment terhadap Pengambilan Keputusan Perawat. Journal of Holistic Nursing Science. Vol:7(2). 124-132.

11. Simamora, R. H.(2019). Menjadi perawat yang CIH'HUY. Surakarta: Kekata Publisher.

12. Simamora, R. H.(2005). Hubungan Persepsi Perawat Pelaksana Terhadap Penerapan Fungsi Pengorganisasian Yang Dilakukan Oleh Kepala Ruangan 
Dengan Kinerjanya Diruang Rawat Inap RSUD Koja Jakarta Utara (Doctoral dissertation, Tesis FIK UI, Tidak dipublikasikan). 